\title{
The report of Prof. Ganslmayer to president Atatürk, about rinderpest and Turkish Veterinary Organization*
}

\author{
Savaş Volkan GENÇ̧1 , Atilla ÖZGÜR²
}

${ }^{1}$ Mehmet Akif Ersoy University, Faculty of Veterinary Medicine, Department of History of Veterinary Medicine and Deontology, Burdur/TURKEY

${ }^{2}$ Ankara University, Faculty of Veterinary Medicine, Department of History of Veterinary Medicine and Deontology, Ankara/TURKEY

\section{Key Words:}

Mustafa Kemal Atatürk

Hans Ganslmayer

rinderpest

Anahtar Kelimeler:

Mustafa Kemal Atatürk

Hans Ganslmayer

sığır vebası

Received: 24.10 .2018

Accepted: 13.10.2018

Published Online: 31.12 .2018

Article Code: 474461

Correspondence

SV. GENC

(svgenc@mehmetakif.edu.tr)

ORCİD:

SV. GENÇ: 0000-0002-9153-060X

A. ÖZGÜR: 0000-0002-8450-282X

* This study is the expanded revised version, which was prepared for publication, of the poster presented with the same name in the 16th Annual Conference and Methodology Seminar "From the campaign against rinderpest to consumer protection: The Development of the Public Veterinary Services" carried out in Germany-Berlin on 11-12 November 2011

\begin{abstract}
Prof. Dr. Hans Ganslmayer came Turkey in 1926 and worked as an expert for 2 years at Military Veterinarian Bacteriology and Serology Institute in Ankara. He sent a mail to President Mustafa Kemal, after his duty ended and returned back his country. He reported his views on Military and Civil Veterinary Medicine in Turkey in his letter. In addition, he presented his views on fighting against cattle plague that created great distress at that time in Turkey. He also gave information about properties, production of vaccines, and supplementation from abroad in this fight. Prof. Ganslmayer also reported the current situation of the Military and Civil Veterinary Organizations with their pluses and minuses and he added the legislation on veterinary medicine is inadequate and should be changed. Ganslmayer was one of the foreign scientists came to Young Republic after 1923. Recommendations in his letter matched up with the succeeded veterinary services in the first 15 years of the Republic.
\end{abstract}

\section{Prof. Ganslmayer'den Atatürk'e Türk Veteriner Hekimliği Teşkilatı ve sığır vebası mücadelesi hakkında rapor}

ÖZ

Prof. Dr. Hans Ganslmayer 1926 yılında Türkiye’ye gelmiș ve iki yıl Ankara'da Askeri Veteriner Bakteriyoloji ve Seroloji Enstitüsünde uzman olarak çalıșmıștır. Görevinin sonunda ülkesine döndükten sonra Cumhurbaşkanı Mustafa Kemal'e bir mektup göndermiştir. Mektupta Türkiye'de Askeri ve Sivil Veteriner Hekimlik Teşkilatı hakkında görüșlerini bildirmiștir. Ek olarak Türkiye'de o dönemde büyük sıkıntılar yaratan sığır vebası hastalığı ile mücadele konusunda görüşlerini aktarmıştır. Bu mücadelede kullanılacak aşıların özellikleri, üretimi ve yurt dışından temini hakkında bilgi vermiştir. Prof. Ganslmayer, o dönemde Askeri ve Sivil Veteriner Hekimliği Teşkilatlarının durumlarını eksi ve artılarıyla aktarırken, veteriner hekimliği mevzuatının yetersizliği ve değiștirilmesi gerektiğini de söylemiştir. Ganslmayer 1923 ten sonra Genç Cumhuriyete gelen ilk yabancı bilim insanlarından biridir. Mektubundaki öneriler cumhuriyetin ilk 15 yılında yapilan başarı ile sonuçlanan veteriner hekimliği hizmetleri ile örtüşmektedir.

\section{INTRODUCTION}

The outbreak of cattle plague, one of the greatest catastrophes of pre-industrial society, has caused great devastation in agricultural production as well as loss of animal products in history (1). There are descriptive information's about cattle plague from ancient Indian inscriptions (2000 BC) to Kahun Papyrus in Ancient Egypt (1900 BC). Vergilius described the disasters caused by disease in his study Georgica $(2,3,4)$. At the first ages, disease has spread from the east of China to Aral and Hazar regions and then to Europe by the Hun attacks. In the next centuries, Asia oriented epidemics continued spreading $(5,6)$. Cattle plague epidemics in Europe in the $18^{\text {th }}$ century has effected the beginning of scientific veterinary medicine education and primary impulsive factor on meeting of the first international veterinary medicine congress in $1863(7,8,9)$. The disease had appeared in several regions of Europe in the $19^{\text {th }}$ century and the last biggest epidemic had seen during France-Prussian War (1870-1871) (10, 11, 12). Later then, the disease was seen only in the Eastern Europe and Asia due to preventive actions taken by the Western and Middle European countries, so the disease spread from Turkey to Bulgaria and Romania in 1913, but defeated rapidly. "The Office International Epizooties" and "Food and Agriculture Organization of the United Nations" had been established to protect the world from catastrophic destruction and epidemics caused by continuing epidemics in Asia $(6,13)$.

Rinderpest had become one of the factors opened the way for scientific enlightenment. The "Spontaneous Generation", the theory of disease once upon a time, was destroyed. It also destroyed the monopoly of the church and the clergy on the treatment of animal diseases and led the replacement of Hippocratic-Galenic treatments to modern scientific treatments $(6,11)$.

Rinderpest had been causing 200 million cattle to die till the $20^{\text {th }}$ century with high morbidity and mortality rates. In the $18^{\text {th }}$ and $19^{\text {th }}$ centuries, vaccination studies similar to smallpox have been carried out but couldn't succeed $(14,11)$. Finally, in 1893, a Russian Veterinarian Eugen Semmer took a crucial step in fighting against this disease by finding the healing properties 
of the immunized sera of surviving cattle, and another vital step was made by Robert Koch with developing it (2, 9, 15).

Eventually, the virus was discovered in 1902 by Adil Mustafa Sehzadebasi and Maurice Nicolle at "The Imperial Bacteriological Laboratory" in Istanbul. Adil Bey and Nicolle defined the organism as a virus that can pass through the filters (16). This laboratory was established in 1901 and produced serum against cattle plague, but this was not enough for the large geography of Ottoman Empire. In 1914, an Institute was opened in Pendik, Istanbul $(2,17)$.

There is no significant information about cattle plague cases except the records of Âli in the Ottoman Empire archives up to the $19^{\text {th }}$ century. After Proclamation of Tanzimat (Ottoman Reform-1839), epidemic news started breaking out with certain intervals. Major animal losses were seen in eastern provinces during the Ottoman-Russian War (1877-1878). Some authors described it as "disaster coming with immigrants" (6, 18). European scientists of that period declared that Anatolia was source of cattle plague and the disease could easily be spread to Thrace. During the next years, the disease continued to be seen in Turkey; and caused big damage during the World War I (WWI) and Turkish War of Independence (6).

After Turkish War of Independence, Republic was proclaimed under the leadership of Mustafa Kemal and the new system was established on secular and scientific bases and this conception was applied on all fields. As a reflection, national studies on veterinary medicine field were supported with international cooperation. In this period, the young Republic's most important agenda item was fighting against rinderpest. These efforts have always been a source of pride for the veterinary medicine, in the history of Turkish veterinary medicine field (19).

There has no such letter found recently presented directly to President Atatürk by a veterinarian other than Ganslmayer's Letter in Turkish Veterinary History studies. Aims of this article are to make a contribute to the history of veterinary medicine in particular and to the history of science in general, and as a step towards the studies to be carried out in this subject.

\section{MATERIALS and METHODS}

Prof. Dr. Hans Ganslmayer (Picture 1) from Vienna, who came to Turkey within the framework of international cooperation, worked in Ankara in "Askeri Veteriner Bakteriyoloji ve Seroloji Enstitüsü” (Picture 2) (Military Institute of Veterinary Bacteriology and Serology) (20). After completing his duty, Ganslmayer presented a report/letter to President Mustafa Kemal Atatürk about construction of Turkish Military and Civilian Veterinary Medicine and struggle against rinderpest (Picture 3-4-5-6) ${ }^{1}$. The subject letter of the work was reached from the State Archives of the Prime Ministry of the Republic of Turkey. Ganslmayer's youth photo and short biographical information were obtained with the help of Prof. Dr. Johann Schaffer from Dr. Christa Mache. It was sent from the Vienna Veterinary Faculty Archives. The information in the letter was evaluated with retrospective approach and with the light of information published before in the field of ${ }^{1}$ BCA: 030.10./186.282.16 veterinary medicine history.

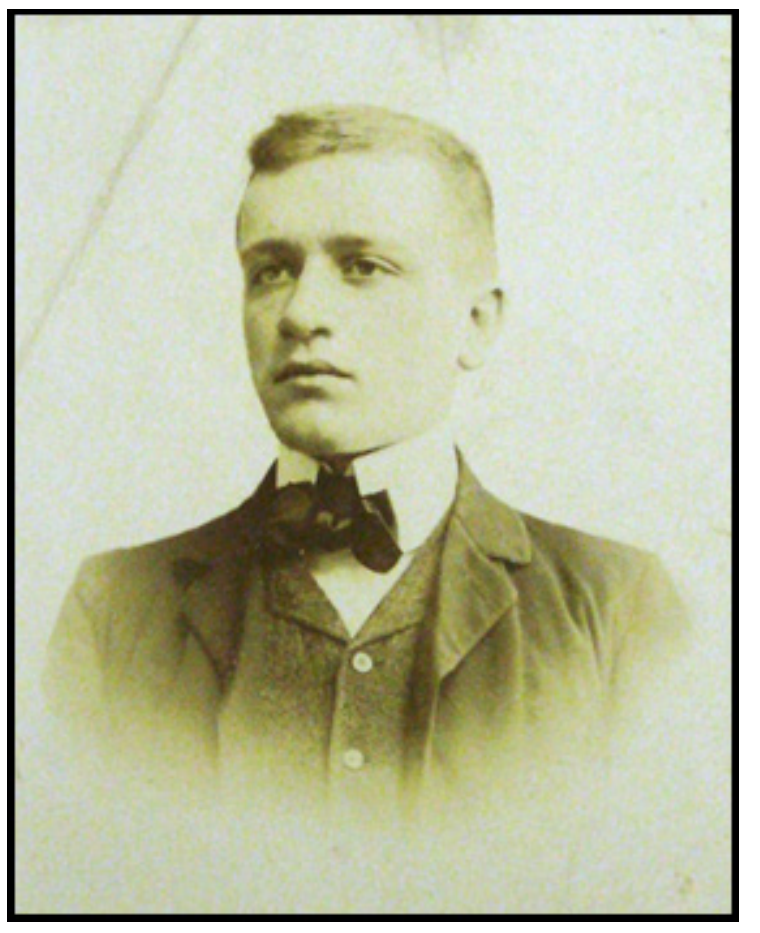

Picture 1 Prof. Dr. Hans Ganslmayer, While he was a student at the Vienna (Veterinary faculty Vienna University of Veterinary Medicine Library Archive Johann Ganslmayer Bildkatalig Nr.I.).

\section{RESULTS}

Prof. Dr. Hans Ganslmayer ${ }^{2}$ worked as an expert veterinarian between 21.01.1926-01.11.1928 in Ankara and as a Manager and Scientist at the Military Veterinary Bacteriology and Serology Institute. Ganslmayer gave his opinion to President Gazi Mustafa Kemal himself about the Turkish Military and Civilian Veterinary Medicine Organization and the thoughts of these Organizations about fighting against cattle plague at the end of his duty.

\section{Military Veterinary Organization:}

According to Hans Ganslmayer; management structure of veterinary medicine in Turkish Army was in European standards except rinderpest struggle. The vaccines produced in Turkey were insufficient. The production of sufficient quantities of serum was taking much time. This difficulty was well known during the war by the leaders of the army. Army was not prepared enough against cattle plague in emergency states. Necessary prediction was missing on veterinary medicine applications in the Army and this caused failure in the concrete situations. The service was sufficient in normal situations. $^{4}$

Prof. Ganslmayer explained these conceptions in a meeting where Veterinary Medicine Ahmet Pasha ${ }^{5}$ also attended. He

${ }^{2}$ Ganslmayer was born in 1885. In 1903 he entered the Vienna Veterinary College and graduated in 1908 (Vienna University of Veterinary Medicine Library Archive Matrikel Nr: 275).

${ }^{3}$ BCA: 030.10./186.282.16

${ }^{4}$ BCA: 030.10./186.282.16

${ }^{5}$ Veterinary Physician Brigadier General Ahmet Vefik Yazgan was the Head of Veterinary Department of the Ministry of National Defense between 03.06.1923 - 04.08.1932 (21). 


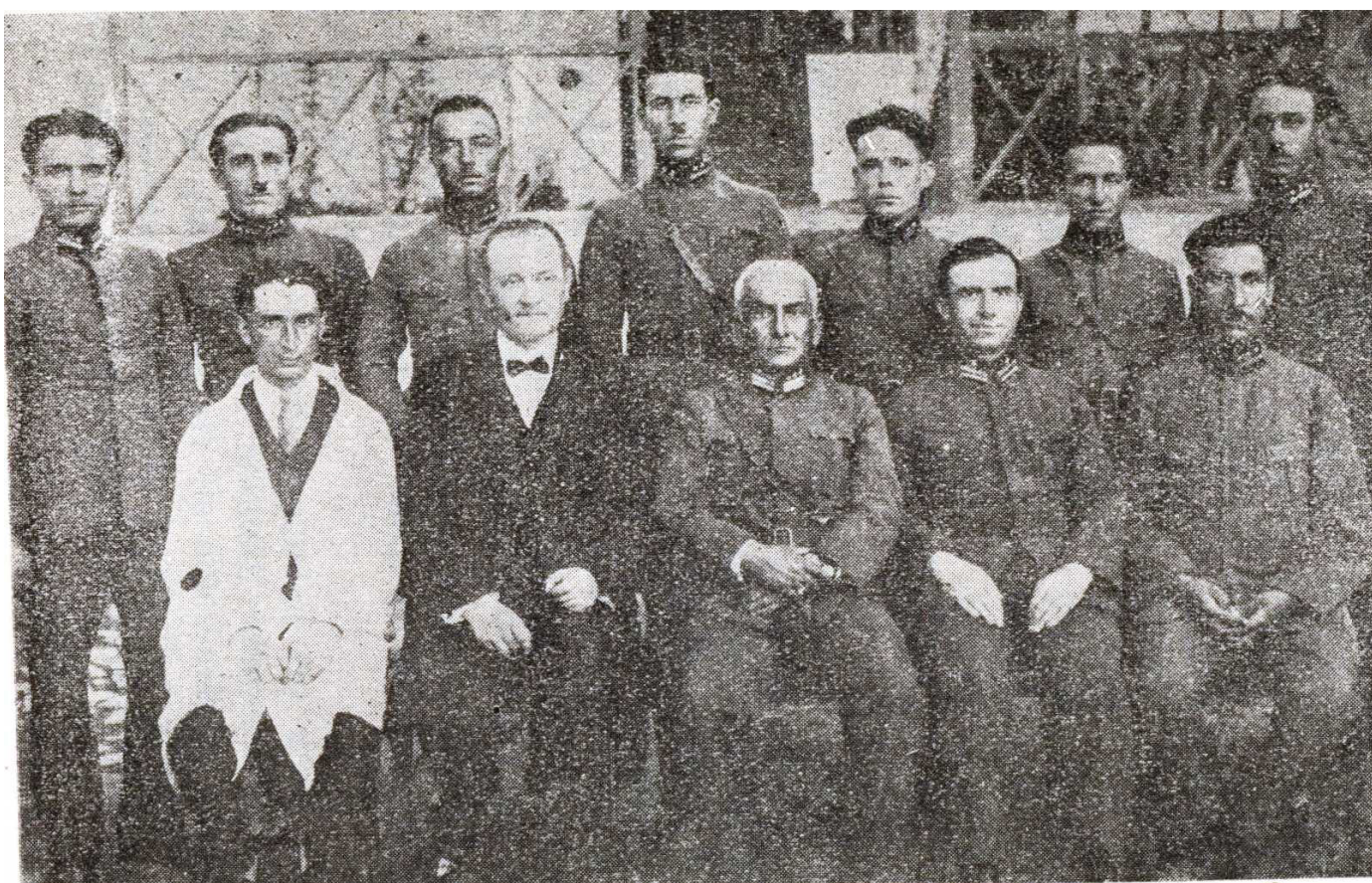

Picture 2 Prof. Ganslmayer with Military Institute of Veterinary Bacteriology and Serology staff (2)

also reported that the liquid vaccine produced against cattle plague (serum against cattle plague) was not useful and was rapidly degrading. He also stated that the powder serum was not affected from cold and warm and would provide immunity for ten years, but liquid serum didn't have these advantages. He said the measures taken against cattle plague could reach wide audiences if they could produce huge amounts of dry serum. He said that if the dry serum was produced in large quantities and distributed individually to the soldiers, the epidemic would be prevented reliably. Prof. Ganslmayer's opinions were welcomed positively and accepted appropriate as for the purpose of struggle, but nothing else had been done. At the same period, he also presented his opinions to the Ministry of Economics. The Ministry realized the practical importance of the situation, taken action and started dry serum production. ${ }^{6}$

The work that the professor had started was very important; he thought that it would especially be very useful for the army. That's why after the first production, he asked the President for a million doses of rinderpest vaccine to be produced and he wanted the production of vaccine to be done for the public after meeting the army's need.

\section{Civilian Veterinary Organization:}

According to Prof. Ganslmayer, Civilian Veterinary Organization's work field was wider and its situation was harder than Military Veterinary Organization. While Turkish Economy was stabile before the revolution of 1923, economy policy of the modern Republic Government was developing rapidly. The economic policy established by the İsmet Pasha Government was successful and would be an example to Europe. In economic life, the Civil Veterinary Service had important duties. These were to keep animal husbandry at the highest level and to provide livestock income constantly so

${ }^{6}$ BCA: 030.10./186.282.16

${ }^{7}$ BCA: 030.10./186.282.16 that consumers could supply food to country from their own products. According to Ganslmayer, the civilian veterinary medicine structure of Turkey was not ready because they couldn't catch up with the modern developments. Although the administrative crew was well developed, the qualifications of the veterinary medicines in the lower levels were insufficient. Also there was no hope about veterinary medicine education in near future at his time. ${ }^{8}$

For Ganslmayer, the motivation which was necessary for the management of modern Veterinary Organization was missing. Veterinarians should have resisted all occasions and state must have supplied all facilities for eradication even by force. Authorities must have investigated the economically basis of problems about animal diseases (e.g. cattle plague) and livestock farmers in a modern veterinary medicine organization. Primarily, the positions of lower ranked officers must be exchanged with veterinarians in order to apply current laws effectively. According to the professor, this was not enough and cattle herds must be vaccinated each spring to prevent losses. For the first stage, the state should have covered vaccination expenses for accustoming people to vaccination. There was need for veterinarians and a comprehensive organization to vaccinate all the animals. ${ }^{9}$

Hans Ganslmayer suggested cooperation with international organizations for struggling with disease and referred International Serum-Union in Wien. This organization carried out serum and vaccination services in many countries successfully. He determined that cooperating with this organization while struggling the disease would give back its results in a few years, so in short time Turkish veterinary services would be able to continue the procedure on their own. ${ }^{10}$

${ }^{8}$ BCA: 030.10./186.282.16

${ }^{9}$ BCA: 030.10./186.282.16

${ }^{10}$ BCA: 030.10./186.282.16 


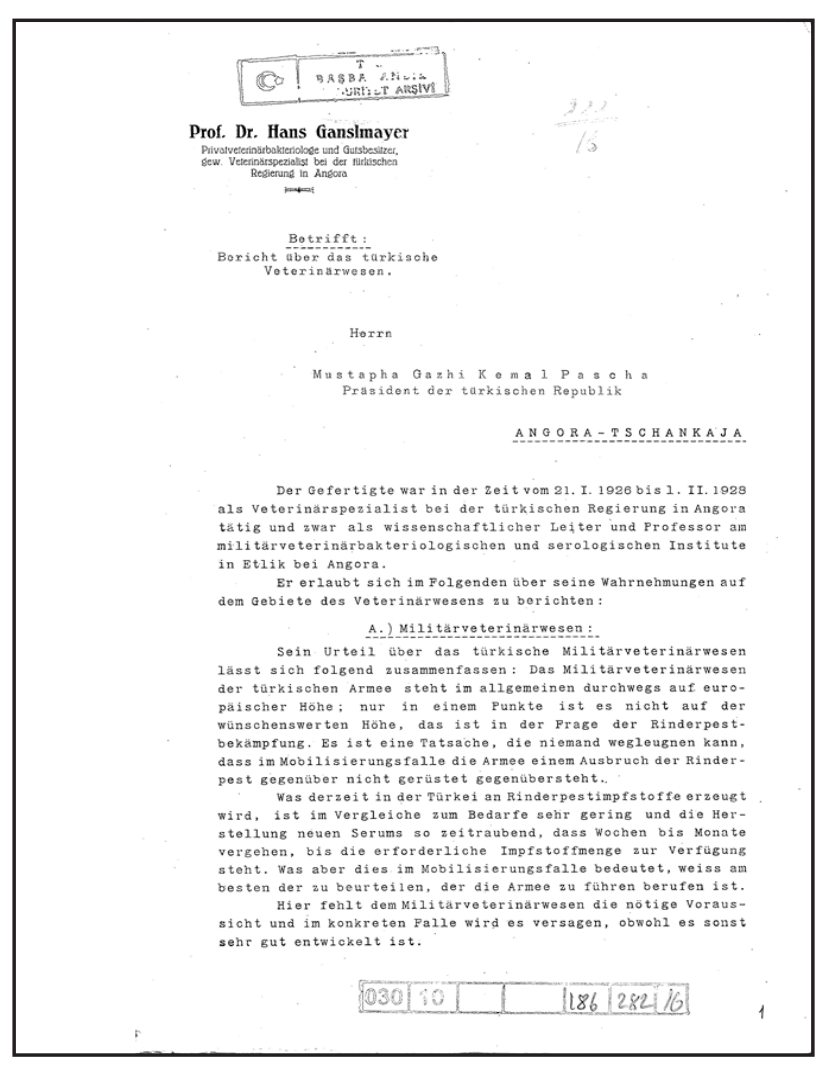

Picture 3 Ganslmayer's Letter Page 1.

\section{B.) Zivilveterinarwesen:}

Das zivilveterinärwesen, die allgemein veterinärpolizei genannt wird, steht vor weitaus grosseren Aufgaben Veterinärwesen des Mili tars; es ist seine Lage daher auch wei taus
schwieriger, Wahrend das Militarveterinarwesen im sinne seiner Traditionen weiterarbeiten kann, muss sich das zivilveterinärwesen mit Rácksicht auf die Umwälzungen in der modernen Türkei wirtschaft charakterisiert durch Leblosigkeit und Unbeweglichkeit. In dẹr modernen Türkei macht die volkswirtschaft eine bedeutende sich stetig steigernde Entwicklung mit, sie ist
charakterisiert durch pulsierendes Leben und lebhafte Beweglich. charakterisiert durch pulsierendes Leben und lebhaf te Beweglich-
keit. Es war ein glacklicher Gedanke im letzten, das heisst keit. Es war ein glacklicher Gedanke im letzten, des heisst
im Jetzigen Kabinetts Ismet Pascha, das volkswirtschaftsministerium gesohaffen zu haben, eine äusserst zweokmàssige Einfuhrung, die vorbildlich fü Europa wirken wird. Im Rahmen
des volkswirtschaftlichen Lebens kommt der veterinărpolizeidie des volkswirtschaftlichen Lebens kommt der Veterinarpolizei die Aufgabe $z$, durch restiose Tilgung der Tierseuchen das Bin-
kommen der Landwirtschaft aus dem Titel der Tierzucht zu einem standigen zu machen, damit die Tierproduktion auf der Hohe zu a1s Konsumenten, aus eigenen Produkten Sorge zu tragen.
Wenn wir uns die Frage vorlegen, ob das turkische zivilveterinärwesen dieser Aufgabe gewachsen ist, dann muss man wesen den Anforderungen der modernen Entwicklung ni o te terinärkann. So gut auch die oberen Veterinarbehörden entwiokelts sejn mögen, die Unterbehorden sind als die wiohtigsten für die Ausubung der veterinärpolizei zu schwach besetzt und es entsteht,

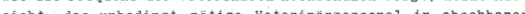
sicht, das unbedingt nötige veterinărpersonal in absehbarer einer modernen veterinärverwaltung vorhanden sein muss, da ist das Streben, die Tilgung der Tierseuchen unter allen Umstanden mit eventueller Aufwendung von Gewalt, die auch direkt mit Rucksichtslosigkeit verbunden sein muss, durchzusetzen und sioh zu diesem zwecke vom Staate alle erforderliohon Mittel zu verKreisen klar machen können, dass bef Fortaauer von Tierseuchen wie Rinderpest u. B. w. der tierzuohttreibende Bauer und dieser ist in der Majorităt, wirtschaftlich zugrunde gehen muss; dieser
Bauer wird bei der năohsten Gelegenheít seine băuerliche rătig. keit verlassen und sein Einkommen in der Industrie (Pabriken), Verdienstmöglichkeit sohon bietet und in den näohsten Jahren $186282 \%$

Picture 5 Ganslmayer's Letter Page 3.
Picture 4 Ganslmayer's Letter Page 2.

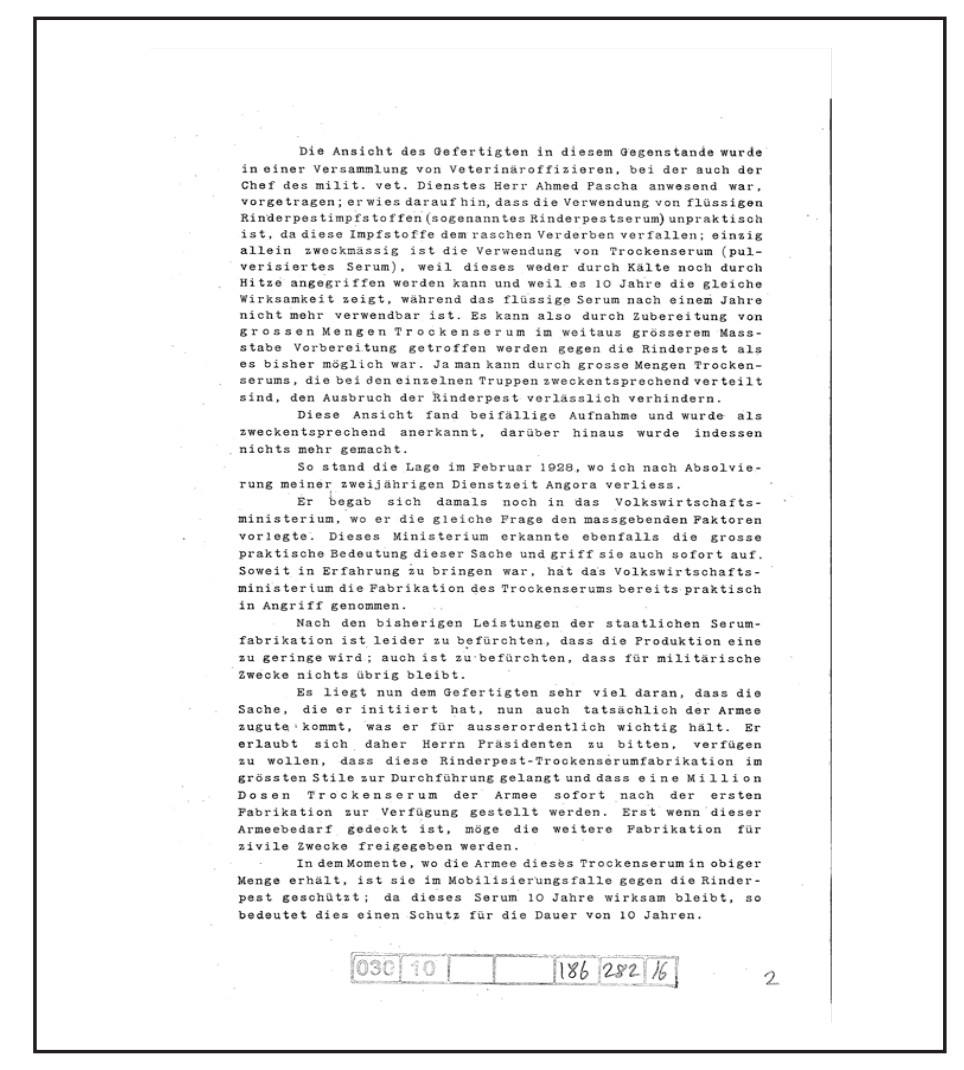

\section{(a)}

noch mehr bieten wird, suchen und auch finden. Die Polgen einer solohen Landifuoht bodeuten aber den Ruin der Landwirtschart in wer stroten des Landes und geranraen die Approvisionierung müssten also bedeutend grössere kittel der veterinärverwaltung zur Verfügung gestellt werden. Zunăchst müssen die untersten
politischen Behörden mit veterinären besetzt werden, damit dio (a)

Der Gefertigte ist der Meinung, dass auch dies nicht genügt, es ist notwendig. zur vermeidung von Tierverlusten all chutzimpfungen, zunächst auf Staats benötigt man Massenvon Impfstoffen, durohzufüren; dazu
bele Impftier arzte und eine umfassende organisation. Hier wäre emp fehlen, erne europaische cesellschart, wie es etwa die in ter solohe Aufgabon in vielon Lutndern schon mit den grasten sirfolgen durohgeführt hat, mit der gesam Serum- und Impfdienstes zu betrauen; die Arbeit dieser gesell. Jahrt unter kontroile der veterinarverwaltung, warde in wenigon türkischen veterinüren Gejegenseit geboten, sich in dion grosszügigen Organisation, die der Volkswirtschaft yiluioner. werte erhalt, zu orientieren und $z u$ lernen und in einigen Jahre Daher erlaubt sich der Gefertig te, Herrn Präsidenten de
d Vorschlag zumachen, von der oben genannten Gesellschaft, di Gutach ten zu ersuohen, wie man am raschesten und ver lässlichste die Rinderpest und auch die anderen Seuchen in der Turkei tilge konnte; es besteht gar kein 2 weifel, dass nach der Durohführun

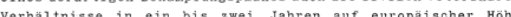
stehen würden.

Zum Sohlusse beehrt sioh der Gefertigte zu berichten,
dass er und seine prau in der tärkisohen Gesellschaft in Btili die beste Aufnahme gefunden haben; sie hatten Gelegenheit die und Gebränophe zu lernen Sie sind für die zwei prächtigen Jahre, die sie th Angora verleben durften, zum grössten Danke verpficiohtet.

(a) Distom Ganshmen

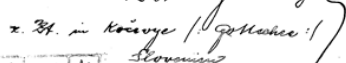
$186[282[16]$ Srovolasion

Picture 6 Ganslmayer's Letter Page 4. 
Prof. Ganslmayer also suggested President Mustafa Kemal to ask for support from the mentioned organizations in order to prevent cattle plague and other epidemics in a short time. After the application of this plan, the Civilian Veterinary Organization could have reached European standards in a year or two. ${ }^{11}$

Ganslmayer had completed his letter saying that they were very well welcomed with his wife, they had opportunity to learn Turkish, had chance to learn the most beautiful traditions and customs of Turkish culture and spent two wonderful years in Ankara. ${ }^{12}$

\section{DISCUSSION and CONCLUSION}

During veterinary medicine history studies in Turkey, there is no other document directly presented to President Atatürk by a foreign or local veterinarian was discovered before Ganslmayer's report. For this feature the document is unique.

The majority of scientific cooperation in the field of veterinary medicine was with France until the WWI. In this manner, the discovery of rinderpest virus can be also an example $(19,22,23,24,25,26,27)$. It is seen that as German scientists took part as academic staff, the scientific cooperation has also changed towards Germany with the opening of the Higher Agriculture Institute (HAI) (Yüksek Ziraat Enstitüsü-YZE) (19, 24, 28). Ganslmayer can be regarded as one of the pioneers of Turkish-German scientific collaboration in the Republican era with his arrival 7 years before establishment of HAI.

Ganslmayer mentioned about the inadequacy of veterinary medicine education in 1920s Turkey and he added corrections must be made. The establishment of HAI Veterinary Faculty in 1933 also shows his ideas about veterinary education were matching with the profits of the Republic. It is also possible that the proposal for free vaccination to be accepted by the public is included in the 1923 Government Program (28).

The dry vaccine Ganslmayer mentioned in his report is the discovery of Ord. Prof. Dr. Süreyya Tahsin Aygün. The success of the vaccination was praised by Dr. Gerlach Geheimrat in 1933 and Prof. Dr. Von Ostertag in 1934 (24). It is obvious from the letter that Ganslmayer didn't mention about the success of this vaccine before his two colleagues from Germany. This may suggest that the international recognition of Aygün's study should be taken further back historically.

Prof. Ganslmayer emphasized on animal diseases in general, but especially focused on fighting against cattle plague in Turkey. The scientific knowledge of veterinarians was low and the legislations were insufficient due to this disease. He presented various measures related to this subject. The proximity of these precautions against cattle plague outbreak in 1932 can be accepted as a sign of scientific dominance overall Turkey $(2,28)$.

Under the leadership of Mustafa Kemal, republic was based on scientific view in the field of veterinary medicine

${ }^{11}$ BCA: 030.10./186.282.16

${ }^{12}$ BCA: 030.10./186.282.16 also like in every aspect on the same basis. For this purpose, national studies in veterinary medicine were supported with international cooperation. Arrival of Ganslmayer in Turkey can also be accepted as one of these examples. The fight against cattle plague became the most important agenda of Republic. This struggle is a pride in the history of Turkish veterinary medicine for veterinarians. All the success achieved in the field of veterinary medicine and animal husbandry is the proof of true scientific point of view of republic $(2,19,28)$.

As a result; Prof. Ganslmayer's report can be considered as one of the important documents in the veterinary field as it is in every subject that Republic put in the way of modernized civilization and it is the first and only recent documents has achieved till now directly written to President Atatürk by a veterinarian in Turkish Veterinary History studies.

\section{ACKNOWLEDGEMENT}

Special thanks to Prof. Dr. Johann SCHAFFER and Dr. Chirista MACHE for their crucial contributions.

\section{REFERENCES}

1.Broad J. Cattle Plague in eighteenth-century England. The Agricultural History Review, 1983; 31:2, 104-115.

2.Erk N, Akkerman NC. Türkiye'de sı̆̆ır vebası salg1nları ve eradikasyonu tarihi. Ankara: Ankara Üniversitesi Veteriner Fakültesi Yayınları, 1969.

3.Maro VP. Çiftçilik sanatı Georgica. İstanbul: Yapı Kredi Yay1nlar1, 2006.

4.Wilkinson L (1992): Animal \& Disease. Cambridge: Cambridge University Press.

5.Dunlop RH, Williams DJ. Veterinary medicine an 1llustrated history. USA: Mosby 1996.

6.Erk N. Tarihte önemli sı̆̆ır vebası salg1nları ve 1920’ye kadar memleketimizdeki durumu. AÜ Vet. Fak. Dergisi, 1963; 10:34, 221-237.

7.Degueurce C. Claude Bourgelat et la création des écoles vétérinaires. Comptes Rendus Biologies, 2012; 335, 334-342.

8.Smithcors JF. Evolution of the veterinary art. London; Tindall and Cox, 1958.

9.Yamanouchi K. Scientific background to the global eradication of rinderpest. Veterinary Immunology and Immunopathology, 2012; 148, 12-15.

10.Erk N. A short history of rinderpest in Turkey. AÜ Vet. Fak. Dergisi, 1975; 22:3-4, 75-78.

11.Vallat F. An outbreak in France in the XVIII ${ }^{\text {th }}$ century: Rinderpest. Comptes Rendus Biologies, 2012; 335, 343-349.

12.Wilkinson L. Rinderpest and mainstream infectious disease concepts in the eighteenth century. Medical History an International Journal for the History of Medicine and Related Sciences, 1984; 28,129-150.

13.Roeder PL. Rinderpest: the end of cattle plague. Preventive Veterinary Medicine, 2011; 102, 98-106.

14.Huygelen C. The Immunization of cattle against rinderpest 
in eighteenth-century Europe. Medical History an International Journal for the History of Medicine and Related Sciences, 1997; 41, 182-196.

15.Sunseri T (2015): The Entangled History of Sadoka (Rinderpest) and Veterinary Science in Tanzania and the Wider World, 1891-1901. Bulletin of the History of Medicine, 89, 92-121.

16.Nicolle M, Adil Bey. Etudes sur la peste bovine. Troisième Mémoire, Ann., Inst., Pasteur, 1902; 16, 56-64.

17.Erk N. İlk Türk bakteriyologlarından Adil Mustafa. AÜ Vet. Fak. Dergisi, 1968; 15:1, 24-28.

18.Ak M. Osmanlı Devleti'nde veba-i bakarî (sığır vebası). OTAM, 2016; 39, 215-240.

19.Dinçer F. 100 years of veterinary microbiological institutes in Turkey. Veterinary Medicine Historical Approaches, , Ankara: p., 2002; 313-325.

20.Anon. T.C. M.S.B. veteriner bakteriyoloji ve serum aşı evi 23 yıllık çalışmaları. Ankara: Yüksek Ziraat Enstitüsü Basımevi, 1945.

21.Dinçer F. Türkiye'de askeri veteriner hekimlik tarihi üzerinde araştırmalar II. bölüm. AÜ Vet. Fak. Dergisi 1982; 27:1-2, 246-272.

22.Bekman M. Veteriner tarihi. Ankara: Ankara Basım ve Cildevi, 1940.

23.Bekman M. Veteriner mikrobiyoloji tarihçesi. Uluslararası Mikrobiyoloji ve Kuduz Symposiumu Kitab1, Ed: Dr. Zekai Muammer Tunçman, s.:71-74, Ankara1968.

24.Dinçer F. Ord. Prof. Dr. Süreyya Tahsin Aygün'ün Hayat1 ve Bilimsel Çalışmaları. AÜ Vet. Fak. Dergisi 1982; 29:1-2, 256-276.

25.Tunçman MZ. Türkiye'de modern mikrobiyolojinin kuruluşunun 75. yıldönümü. Ed: Dr. Zekai Muammer Tunçman, Uluslararası Mikrobiyoloji ve Kuduz Symposiumu Kitabi, s.:339, Ankara, 1968.

26.Tüzdil N. Türk veteriner hekimliği tarihi. Ankara: Ankara Üniversitesi Veteriner Fakültesi Yayınlar1:75, Ders Kitabı:30, 1955.

27.Unat EK. Osmanlı İmparatorluğunda bakteriyoloji ve viroloji. İstanbul: İstanbul Üniversitesi Cerrahpaşa Tıp Fakültesi Yayınlar1, 1970.

28.Başağaç RT. Türkiye'de iki dünya savaşı arasında veteriner hekimliği hizmetleri ve hayvancılık politikaları üzerinde araştırmalar. Ankara: Ankara Üniversitesi Sağlık Bilimleri Enstitüsü Doktora Tezi, 2001. 